\title{
The Health and Housing in Transition Study: A longitudinal study of the health of homeless and vulnerably housed adults in three Canadian cities
}

Version Post-print/accepted manuscript

Citation Hwang SW, Aubry T, Palepu A, Farrell S, Nisenbaum R, Hubley AM, (published version) Klodawsky F, Gogosis E, Hay E, Pidlubny S, Dowbor T, Chambers C. The Health and Housing in Transition Study: A longitudinal study of the health of homeless and vulnerably housed adults in three Canadian cities. International Journal of Public Health. 2011 Dec;56(5):609-623.

Publisher's Statement The final publication is available at Springer via http://dx.doi.org/10.1007/s00038-011-0283-3. 
The Health and Housing in Transition Study: a longitudinal study of the health of homeless and vulnerably housed adults in three Canadian cities

Stephen W. Hwang (1,2), Tim Aubry (3), Anita Palepu (4), Susan Farrell (5), Rosane Nisenbaum (1), Anita M. Hubley (6), Fran Klodawsky (7), Evie Gogosis (1), Elizabeth Hay (3), Shannon Pidlubny (4), Tatiana Dowbor (1), Catharine Chambers (1)

\section{Author affiliations:}

(1) Centre for Research on Inner City Health, the Keenan Research Centre at the Li Ka Shing Knowledge Institute, St. Michael's Hospital, Toronto, Canada

(2) Division of General Internal Medicine, Department of Medicine, University of Toronto, Toronto, Canada

(3) Centre for Research on Educational and Community Services, University of Ottawa, Ottawa, Canada

(4) Centre for Health Evaluation and Outcome Studies, Division of General Internal Medicine, University of British Columbia, Vancouver, Canada

(5) Royal Ottawa Health Care Group, Ottawa, Canada

(6) Measurement, Evaluation, and Research Methodology, Department of Educational and Counselling Psychology, and Special Education, University of British Columbia, Vancouver, Canada

(7) Department of Geography and Environmental Studies, Carleton University, Ottawa, Canada 


\section{Corresponding author:}

Stephen W. Hwang, MD, MPH

Centre for Research on Inner City Health, St. Michael's Hospital

30 Bond Street, Toronto, Ontario M5B 1W8

Email: hwangs@ smh.ca / Phone: 416-864-5991 / Fax: 416-864-5485

Word count (text): 3,980

Word count (abstract): 178 


\begin{abstract}
Objectives: While substantial research has demonstrated the poor health status of homeless populations, the health status of vulnerably housed individuals is largely unknown. Furthermore, few longitudinal studies have assessed the impact of housing transitions on health. The Health and Housing in Transition (HHiT) Study is a prospective cohort study that aims to track the health and housing status of a representative sample of homeless and vulnerably housed single adults in three Canadian cities (Toronto, Ottawa, and Vancouver). This paper discusses the HHiT study methodological recruitment strategies and follow-up procedures, including a discussion of the limitations and challenges experienced to date.

Methods: Participants $(\mathrm{n}=1,192)$ were randomly selected at shelters, meal programs, community health centres, drop-in centres, rooming houses, and single-room occupancy hotels from January to December 2009 and are being re-interviewed every 12 months for a two-year period. Results: At baseline, over $85 \%$ of participants reported having at least one chronic health condition, and over $50 \%$ reported being diagnosed with a mental health problem. Conclusions: Our findings suggest that, regardless of housing status, participants had extremely poor overall health.
\end{abstract}

Keywords: Homeless persons; Vulnerable populations; Housing; Health; Mental health; Quality of life; Longitudinal studies 


\section{Introduction}

Homelessness, defined as living in a shelter, on the street, in other places not intended for human habitation, or in temporary accommodations with family or friends, is an increasingly visible problem that affects thousands of Canadians (Hwang 2001). On any given night, about 5,000 people in Toronto, 900 people in Ottawa, and 2,700 people in Vancouver are homeless (City of Toronto 2009; Dinning and Davis 2008; SPARC BC et al. 2008). Over the course of a year, an estimated 150,000 to 300,000 Canadians will experience homelessness (Laird 2007; Human Resources and Skills Development Canada 2010). Less visible, but equally important, are the large number of people in Canada who are "vulnerably housed", a term that includes lowincome, socially marginalized individuals living in single room occupancy (SRO) hotels and rooming houses. These individuals often have unstable living arrangements, resulting in frequent transitions between homelessness and vulnerable housing. For many, homelessness is an episodic, often temporary, experience as opposed to a chronic state (Aubry and Klodawsky 2003; Culhane et al. 1994).

Housing is a key social determinant of health. A substantial body of research over the last two decades has shown that single adults who experience episodes of homelessness suffer from high rates of physical and mental illness, substance abuse, injuries and assaults, and mortality (Aubry et al. 2011; Frankish et al. 2005; Hwang and Dunn 2005). A recent longitudinal study of Canadian adults found that mortality rates from all causes were 2.01 times higher among men living in shelters, rooming houses, and hotels compared to men in the general population and 1.79 times higher among women (Hwang et al. 2009).

The majority of studies on housing and health among homeless and vulnerably housed populations have used a cross-sectional design, despite the fact that housing status is a dynamic 
state with frequent transitions between homelessness and vulnerable housing. We identified a relatively small number of studies that accounted for longitudinal changes in the health and housing status of representative samples of homeless populations over time (Table 1).

Overall, previous research demonstrates that a substantial number of homeless individuals make a transition into some form of housing over follow-up periods ranging from 18-60 months. However, most of these studies have been conducted in the U.S., and extrapolation of these findings to others settings is problematic for a number of reasons, not the least of which is the different health care systems that operate in the two countries. In Canada, homeless individuals retain their access to health care, in contrast to the U.S., where more than half of all homeless people do not have health insurance (Kushel et al. 2001). Other factors that highlight the need for additional data include the substantial differences between the U.S. and other countries in terms of ethnicity and race, climate, housing markets, social housing policies, extent of the social safety net, and severity of geographic concentration of extreme urban poverty (Dunn et al. 2005; Ross et al. 2000; Ross et al. 2005). For these reasons, longitudinal research of homeless and vulnerably housed people from settings such as Canada is needed to better understand the complex connections between housing and health.

The Health and Housing in Transition (HHiT) Study is a longitudinal cohort study that aims to track the health and housing status of a representative sample of homeless and vulnerably housed single adults in three Canadian cities (Toronto, Ottawa, and Vancouver) over a two-year follow-up period. The specific objectives of this study are:

1. To determine the incidence of housing transitions in these populations, defined as (a) the rate at which homeless individuals exit homelessness, (b) the rate at which 
vulnerably housed individuals become homeless, and (c) the rate at which vulnerably housed individuals attain stable housing by the end of the follow-up period;

2. To identify risk factors and individual, interpersonal, and community-level resources associated with (a) the attainment of stable housing among homeless individuals, (b) the onset of homelessness among vulnerably housed individuals, and (c) the attainment of stable housing among vulnerably housed individuals; and

3. To ascertain whether changes in housing status are associated with subsequent changes in physical and mental health functioning and major health determinants (including access to health care, alcohol and drug use, food security, and social supports).

\section{Methods}

\section{Study setting}

Toronto, Ottawa, and Vancouver are large, urban cities in Canada that vary in terms of their climate, geographic location, population size, and housing markets. Vancouver (pop. 2.2 million) is located in the province of British Columbia, on the west coast of Canada. Toronto (pop. 5.4 million) and Ottawa (pop. 1.2 million) are located in the province of Ontario in eastern Canada, approximately 3,500 km from British Columbia. Average monthly rents for a private one-bedroom apartment in these three cities range from $\$ 853$ to $\$ 926 \mathrm{CDN}$, while vacancy rates range from $1.4 \%$ to $3.0 \%$ (Canada Mortgage and Housing Corporation 2009). Social assistance rates range between $\$ 585$ to $\$ 610 \mathrm{CDN}$ per month for a single adult and between $\$ 906$ to $\$ 1,053$ CDN per month for a single adult with a disability (City of Toronto 2010; Ministry of Housing and Social Development 2007). As can be seen in these figures, affording a market-rent unit is 
moderately to extremely difficult for an individual living on social assistance. As a result, many marginalized individuals depend on a limited supply of lower-cost alternative housing, such as SRO hotels (in Vancouver) and rooming houses (in Toronto and Ottawa) to meet their shelter needs.

\section{Target populations}

Participants were eligible for the study if they were age 18 years or older and did not live with a partner or dependent child (i.e., were single adults). Participants were considered homeless if they were currently living in a shelter, public place, vehicle, abandoned building, or someone else's place and did not have their own place. Participants were considered vulnerably housed if they reported living in their own room, apartment, or place and had been homeless in the past 12 months and/or had two or more moves in the past 12 months. Participants who were temporarily living with friends and family and were paying rent were considered vulnerably housed, while those who were not paying rent were considered homeless. Full-time students and individuals who were visiting the city for less than or equal to three months were excluded.

\section{Recruitment strategy}

Participants were recruited between January and December 2009. We aimed to recruit 600 homeless and 600 vulnerably housed single adults in total (200 homeless and 200 vulnerably housed participants in each of the three cities); however, due to some participants completing more than one interview (using a different name), our final sample was 1,192 participants. In instances where duplicate interviews were identified, we included the first interview only. 
Our sampling plan for recruiting homeless adults was adapted from the design proposed by Ardilly and Le Blanc (2001). Recruitment of homeless adults took place at both shelters and meal programs. Because the purpose of recruitment at meal programs was to recruit homeless people who did not use shelters, single adults at meal programs were eligible if they were homeless but had not stayed at a shelter more than three nights in the last seven days. The target number of homeless participants recruited at meal programs was proportional to the approximate number of homeless adults in each city who slept on the street.

Homeless participants were sampled using a two-stage cluster strategy. Primary sampling units included all shelters and meal programs in each city. In the first stage of sampling, shelters were randomly selected according to probabilities proportional to the number of shelter beds (Kish 1995). Meal programs were selected through a similar process based on location and the estimated number of individuals who were served meals each week. At shelters, participants were selected on the basis of their bed number using a random number list. At meal programs, research and agency staff screened individuals who were in the meal line or had used the meal program and were in the vicinity of the site, and invited those eligible to participate.

The sampling frame for recruiting vulnerably housed participants included all official SROs in Vancouver and licensed rooming houses in Toronto and Ottawa. At SROs and rooming houses where our research team could gain access, we approached all individuals who were living at the site and who were available at the time of the site visit. Due to feasibility challenges associated with sampling at SROs and rooming houses (see Discussion), the target number of vulnerably housed participants (200 in each city) could not be recruited at these sites. Our sampling strategy for recruitment of vulnerably housed participants was therefore modified to include meal programs, drop-ins centres, and community health centres in the sampling frame. 
Selected individuals were told about the nature of the study and assessed for their eligibility and willingness to participate. Individuals who declined to participate or who were not available at the time of recruitment were not re-contacted and were replaced by another randomly selected individual at that site. Duplicate interviews that were identified during the recruitment period were replaced with interviews from another randomly selected individual. All eligible and willing participants provided informed consent and were reimbursed for their time (\$20 CDN) following the baseline interview and at each subsequent interview. Ethical approval for this study was obtained from the Research Ethics Board at St. Michael's Hospital (Toronto), the University of Ottawa, and the University of British Columbia (Vancouver).

\section{Follow-up procedures}

At the present time, participants are being re-interviewed approximately every 12 months over the two-year period following their baseline interview. The goal of our study is to achieve an $80 \%$ retention rate, using methods shown to be effective at tracking and retaining homeless and vulnerably housed participants (McKenzie et al. 1999). Efforts were made to establish trust and rapport with participants at first contact and to explain the importance of their participation in follow-up interviews. At the time of enrolment, participants were asked to provide contact information not only for themselves but also for friends, relatives, service providers, and case workers who were most likely to know their future whereabouts and who could be contacted in order to locate them. Participants were asked to give consent for municipal social services departments, hospitals, homeless shelters, prisons, and treatment centres to disclose their updated contact information to the research team (Aubry et al. 2004; Aubry et al. 2007; Aubry and 
Klodawsky 2003). Tracking efforts were modified during the study period and were further tailored to the individual circumstances in each city.

\section{Survey instrument}

Data were obtained using structured in-person interviews, which took approximately 6090 minutes to complete. The survey instrument (Table 2) contains validated scales and questions that were selected on the basis of relevance to and previous successful use among homeless and vulnerably housed people, having very good to excellent psychometric properties, being sensitive to change over time, and being easy to administer. Open-ended questions were also included to further probe participants' understandings of causal interactions between homelessness and health. A pilot study conducted in 2007 included 55 participants and demonstrated the feasibility of sampling, recruitment, and survey administration strategies. Based on our experiences during pilot testing, the questionnaire was shortened and revised for greater reliability and ease of administration.

Age was calculated by subtracting the participants' reported date of birth from their date of interview. Health status was assessed using the Short Form 12-item health survey (SF-12), which provided reliable physical and mental health summary measures, according to the publishers' specifications (Ware et al. 1995). SF-12 Summary Component Scores range continuously from 13 to 69 for physical health (PCS) and 10 to 70 for mental health (MCS), and are standardized to the general population in the United States (mean score of 50 and standard deviation of 10) (Ware et al. 1995). Higher scores represent better overall health status. Health conditions, use of health services, and barriers to accessing health care were assessed using selfreport items adapted from the National Survey of Homeless Assistance Providers and Clients 
(Burt et al. 1999) and the Canadian Community Health Survey (Statistics Canada 2010). A history of previous mental health diagnoses were assessed through self-report.

Alcohol abuse was assessed using the Alcohol Use Disorders Identification Test (AUDIT), which is used to identify the preliminary signs of hazardous drinking and mild dependence, and scores were calculated according to the publisher's specifications (Babor et al. 2001; Piccinelli et al. 1997). AUDIT scores of eight or more were considered indicative of hazardous or harmful alcohol use, as well as possible alcohol dependence. Drug abuse and the degree of problems related to drug use were assessed using the 10-item version of the Drug Abuse Screening Test (DAST-10), and scores were calculated according to the publisher's specifications (Gavin et al. 1989). DAST-10 scores of three or higher were considered indicative of moderate, substantial, or severe drug use problems. Use of injection and non-injection drugs were assessed using items developed by Roy and colleagues (2004). Smoking was assessed using items from the Canadian Community Health Survey (Statistics Canada 2010).

Quality of life was assessed using two complementary instruments. The Quality of Life for Homeless and Hard to House Individuals (QoLHHI) Instrument addresses general and specific quality of life issues that have been identified as important to homeless people (Hubley et al. 2009; Russell et al. 2008). The EuroQol (EQ-5D) is a standardized health-related quality of life instrument that generates a weighted composite score reflecting the preference value associated with a given health state, and a global rating of current health using a visual analog scale (VAS) (Krabbe and Weijnen 2003; Rabin and de Charro 2001). EQ-5D scores range between -0.11 and 1.00 for the U.S. general population, where a score of 0.0 represents death and 1.0 represents perfect health (Shaw et al. 2005). VAS scores range from 0 to 100. Further details 
regarding participants' perceptions and experiences about various aspects of their lives (e.g., food quality/availability, neighbourhood, etc.) were obtained through open-ended questions.

Social support was assessed using two instruments: (1) the Social Provisions Scale, which examines the provision of social relationships (Cutrona and Russell 1987); and (2) the Social Support Network Inventory (SSNI), a self-report questionnaire that measures the size of a person's social network and perceived social support (Flaherty et al. 1983). Social services utilization in the past 12 months was assessed through self-report.

Housing status over the preceding two years was determined using the Housing Timeline Follow-Back Calendar (HTFBC), a validated method that allows for the collection of detailed and accurate information on housing history (Tsemberis et al. 2007). The Housing Quality Score developed by Toro and colleagues (1995) was used to determine the self-reported quality of the current living environment in terms of comfort, safety, spaciousness, privacy, friendliness, and overall quality. If the participant was housed, we determined if they were living in market-rent or subsidized rent-geared-to-income housing using questions developed for the Ontario Community Mental Health Evaluation Initiative (Dewa et al. 2002; Dewa et al. 2004). Additional open-ended questions were included to explore participants' past experiences of housing and homelessness, and their perception of the links between housing and health.

\section{Statistical analyses}

Comparisons were made between participants who were homeless at baseline to those who were vulnerably housed. The two-sample t-test was used for continuous variables and chisquare test was used for categorical variables. In instances where distributions for continuous 
variables were skewed, the non-parametric Wilcoxon rank-sum test was used. All analyses were performed using SAS statistical software version 9.2 (SAS Institute, Cary, NC).

\section{Results}

In total, 1,192 participants were recruited into our study: 396 (33.2\%) in Vancouver, 399 (33.5\%) in Toronto, and 397 (33.3\%) in Ottawa. Our final sample consisted of 595 (49.9\%) homeless participants and 597 (50.1\%) vulnerably housed participants. Selected baseline comparisons between homeless and vulnerably housed participants are provided in Table $\mathbf{3}$. Significant differences between the two groups were noted for certain demographic characteristics. Compared to homeless participants in our sample, vulnerably housed participants were more likely to be born in Canada, be of First Nations/Aboriginal ethnicity, and have lower education levels. Vulnerably housed participants were less likely to be female; however, this difference likely results from our sampling design, which over-sampled females at homeless shelters to ensure adequate sample size, rather than a true difference in population characteristics.

Among the vulnerably housed sample, 222 (40.0\%) reported living in subsidized housing. Participants who were vulnerably housed reported spending a median of \$388 Canadian dollars per month on rent, which corresponds to approximately $43 \%$ of the median monthly income for this sample. However, we expect that in reality this proportion is even higher, as many participants may have been unaware that they were living in subsidized housing and/or were unaware of what portion of their income was being put towards their housing subsidies. Both samples reported spending a considerable amount of time without housing in their lifetimes; the median lifetime duration of homelessness among all participants was 2.8 years. 
In terms of baseline health status, over $85 \%$ of participants reported having at least one chronic health condition, and over $50 \%$ reported being diagnosed with a mental health problem. The mean health composite scores from the SF-12 health survey were 44.5 (standard deviation=11.3) for physical health and 39.1 (standard deviation=13.0) for mental health. Vulnerably housed participants had slightly lower SF-12 PCS and were more likely to report a greater number of chronic health conditions than homeless participants; whereas, homeless participants reported very slightly lower SF-12 MCS than vulnerably housed participants.

\section{Discussion}

Our baseline findings suggest that - regardless of housing status - participants had extremely poor overall health. Compared to the U.S. general population, SF-12 PCS were 0.5 standard deviations lower than expected and MCS were more than one standard deviation lower than expected (Ware et al. 1995). While substantial prior research has demonstrated the poor health status of homeless populations in Canada (Aubry et al. 2011; Frankish et al. 2005; Hwang and Dunn 2005), minimal research is available regarding the health status of individuals living in socially marginalized, inadequate housing. In our study, we show that vulnerably housed participants had equally poor, and in some cases worse, health status than individuals who had no housing at all.

The HHiT Study is an ambitious multi-site study that aims to address a gap in the research around the impact of housing transitions on health. The strengths of this study include the longitudinal design, the multi-site approach, the relatively large sample size, the inclusion of both homeless and vulnerably housed populations, and the use of validated survey instruments and scales. Additionally, we are using recruitment and tracking methods that have been shown to 
be effective for these populations and that have been used previously by our research team (Ardilly and Le Blanc 2001; Aubry et al. 2004).

However, despite these strengths, a number of challenges have been encountered to date. Among our biggest challenges has been gaining access to SROs and rooming houses to recruit vulnerably housed participants. These challenges include: difficulties obtaining up-to-date, accurate lists of SROs and rooming houses from municipal sources; physical barriers such as missing buzzers or inaccurate tenant lists; landlords who would not respond to multiple requests to visit the site for the purpose of recruiting participants; and sites no longer being in operation at the time of recruitment. Furthermore, at sites that were accessible, very few residents were available, willing, or eligible to participate, despite multiple visits on different days and times. Many individuals who were located at SROs and rooming houses had lived at these residences for numerous years and, in this sense, were stably housed and deemed ineligible for our study. For these reasons, we modified our sampling strategy to include sampling of vulnerably housed participants at meal programs, community health centres, and drop-in centres, which proved to be more accessible for our research staff. Additional challenges included participants not arriving at scheduled interview times, difficulty in finding private and safe locations to conduct interviews, shelter restrictions that limited the times when participants were present at the site, and identification of individuals who completed the interview more than once, as some participants gave false names so that they could participate multiple times. In order to overcome these challenges, whenever possible we conducted interviews immediately after a participant was recruited and deemed eligible, used nearby community-based locations to conduct interviews, and cooperated with shelter staff to help with random selection of homeless participants at shelters. Thorough checks based on name, sex, date of birth, and health card number were 
performed each day; however, despite these efforts, we identified 8 individuals who were interviewed more than once following the end of our recruitment period, resulting in a lower sample size than originally planned.

This study has certain limitations that should be acknowledged. Our study design does not sample homeless populations who do not use either shelters, meal program, community health centres, or drop-in centres; however, prior research suggests that this subgroup of homeless people is very small (Crowe and Hardill 1993; Hardill 1993). As well, due to the recruitment issues noted above, our study does not include a random sample of vulnerably housed participants. Individuals considered vulnerably housed who do not use meal programs, drop-in centres, or community health centres and/or who reside in inaccessible or unidentified SROs or rooming houses may have been missed. In this sense, our sample strategy may have overlooked extremely marginalized or hard-to-reach populations. We also restricted our sample to single adults who were not living with a partner or dependent children. However, as this study was meant to examine the effect of housing transitions on health over time rather than provide an overall assessment of the health status of vulnerably housed populations in Canada, concerns over the generalizability of our sample are lessened. Our sample may be biased towards only those individuals who are fluent in English or French (the two official languages in Canada). Although interpretation services for other languages were available, it was often not possible to determine a potential participants' preferred language and frequently difficult to re-locate the participant when the interviewer returned with an interpreter.

While we made efforts to ensure that participants were unaware of our eligibility criteria, some participants may have lied about their housing status in order to participate. This issue was especially true during recruitment at meal programs where potential participants were 
approached within a common area. While this study attempts to explore individual-level factors associated with housing transitions, contextual factors such as concurrent programs and policies occurring at the municipal- or provincial-levels that differ across study sites may influence our incidence rate calculations. For example, the 2010 Olympic Games in Vancouver may have resulted in a precipitous loss of low-cost housing options during our follow-up period, as developers sought to provide profitable accommodations for Olympic visitors and gentrify the neighbourhoods where affordable housing was located (Lenskyj 2002). In order to address this issue, we will stratify our incidence rate calculations by study site.

The paucity of longitudinal research on homelessness and health in Canada restricts our understanding of the course of homelessness, the factors that help individuals escape homelessness, and the effectiveness of services and supports to address homelessness. Identification of these factors holds significant promise as a source of information to guide the creation of effective social and health programs and policies (Hartig and Lawrence 2003). This multi-site longitudinal study of the health and housing status of homeless and vulnerably housed adults in Canada will provide important insights into the role of housing as a social determinant of health for disadvantaged populations. Data from this study will be used to determine the incidence of housing transitions among homeless and vulnerably housed adults over a 2-year period, the resources and risk factors associated with the attainment of stable housing and the onset of homelessness, and whether changes in housing status are associated with changes in health status, quality of life, and major health determinants. 


\section{Acknowledgements}

This project was supported by an operating grant (MOP-86765) and an Interdisciplinary Capacity Enhancement Grant on Homelessness, Housing and Health (HOA-80066) from the Canadian Institutes of Health Research. The Centre for Research on Inner City Health in the Li Ka Shing Knowledge Institute at St. Michael's Hospital gratefully acknowledges the support of the Ontario Ministry of Health and Long-Term Care. The authors thank Ying Di, Centre for Research on Inner City Health, for her expert programming and analyses. We would like to acknowledge the following individuals from our community partner organizations: Laura Cowan, Liz Evans, Sarah Evans, Stephanie Gee, Clare Haskel, Erika Khandor, and Wendy Muckle. The authors also thank the shelter, drop-in, and municipal and provincial staff for their assistance with participant recruitment and follow-up. The views expressed here are the views of the authors and do not necessarily reflect the views of the Ontario Ministry of Health and LongTerm Care or any of the other named individuals or organizations. 


\section{Reference list}

Ardilly P, Le Blanc D (2001) Sampling and weighting a survey of homeless persons: a French example. Surv Methodol 27:109-118.

Aubry T, Klodawsky F (2003) Panel study on persons who are homeless in Ottawa: Phase One results. City of Ottawa, Ottawa.

Aubry T, Klodawsky F, Hay E, Nemiroff R, Hyman S (2004) Developing a methodology for tracking person who are homeless over time. Final Report. Canada Mortgage and Housing Corporation, Ottawa.

Aubry T, Klodawsky F, Nemiroff R, Birnie S, Bonetta C (2007) Panel study on persons who are homeless in Ottawa: Phase Two results. Centre for Research on Community Services, University of Ottawa, Ottawa.

Aubry T, Klodawsky F, Coulombe D (2011) Comparing the housing trajectories of different clusters within a diverse homeless population. Am J Community Psychol 2011 May 10 [Epub ahead of print].

Babor TF, Higgins-Biddle JC, Saunders JB (2001) AUDIT: The Alcohol Use Disorders Identification Test: Guidelines for use in primary care. World Health Organization, Department of Mental Health and Substance Dependence, Geneva.

Burt MR, Aron LY, Douglas T, Valente J, Lee E, Iwen B (1999) Homelessness: programs and the people they serve. Findings of the National Survey of Homeless Assistance Providers and Clients. Interagency Council on the Homeless, Washington, DC.

Canada Mortgage and Housing Corporation (2009) Housing market information. Rental market reports - major centres. https://www03.cmhc- 
schl.gc.ca/catalog/productList.cfm?cat=79\&lang=en\&fr=1287667818008. Accessed 21

October 2010.

City of Toronto (2009) Street needs assessment results. Shelter, Support, and Housing Administration, City of Toronto, Toronto.

City of Toronto (2010) Employment and social services. http://www.toronto.ca/socialservices/. Accessed 21 October 2010.

Crowe C, Hardill K (1993) Nursing research and political change: the Street Health report. Can Nurse 89:21-24.

Culhane D, Dejowski EF, Ibanez J, Needham E, Macchina I (1994) Public shelter admission rates in Philadelphia and New York City: the implications of turnover for sheltered population counts. Housing Policy Debate 5:107-140.

Cutrona CE, Russell D (1987) The provisions of social relationships and adaptation to stress. In: Jones WH, Perlman D (eds). Advances in personal relationships, vol 1. JAI Press, Greenwich, pp 37-67.

Dinning LB, Davis C (2008) Community action plan on homelessness: 2009-2014. The road to ending homelessness in Ottawa. The Homelessness Community Capacity Building Steering Committee, Ottawa.

Dewa CS, Durbin J, Eastabrook S, Ochoka J, Boydell K, Wasylenki D, et al. (2002) Considering a multi-site study? Taking the leap and having a soft landing. J Community Psychol 30:115.

Dewa CS, Butterill D, Durbin J, Goering P (2004) No matter how you land: challenges of a longitudinal multi-site study. Can J Program Eval 19(3 Special Issue):1-28. 
Dunn JR, Burgess B, Ross NA (2005) Income distribution, public services expenditures, and all cause mortality in US States. J Epidemiol Community Health 59:768-774.

Flaherty JA, Gaviria FM, Pathak DS (1983) The measurement of social support: the Social Support Network Inventory. Compr Psychiatry 24:521-529.

Frankish CJ, Hwang SW, Quantz D (2005) Homelessness and health in Canada. Can J Public Health 96:23-29.

Gavin DR, Ross HE, Skinner HA (1989) Diagnostic validity of the drug abuse screening test in the assessment of DSM-III drug disorders. Br J Addict 84:301-307.

Hardill K (1993) How the Street Health survey was one: developing a methodology for survey research with homeless women and men. Street Health, Toronto.

Hartig T, Lawrence RJ (2003) Introduction: The residential context of health. J Soc Issues 59:455-473.

Hubley AM, Russell LB, Gadermann AM, Palepu A (2009) Quality of life for homeless and hard-to-house individuals (QoLHHI) inventory: administration and scoring manual. Vancouver. http://educ.ubc.ca/faculty/hubley/qolhhi/QoLHHI\%20Manual.pdf.

Human Resources and Skills Development Canada (2010) The homelessness partnering strategy. http://www.hrsdc.gc.ca/eng/homelessness/index.shtml. Accessed 16 September 2010.

Hwang SW (2001) Homelessness and health. CMAJ 164:229-233.

Hwang SW, Dunn JR (2005) Homeless people. In: Galea S, Vlahov D (eds). Handbook of urban health: populations, methods, and practice. Kluwer/Plenum, New York, pp 19-42.

Hwang SW, Wilkins R, Tjepkema M, O'Campo PJ, Dunn JR (2009) Mortality among residents of shelters, rooming houses, and hotels in Canada: 11 year follow-up study. BMJ 339:b4036. 
Kish L (1995) Survey sampling. John Wiley, New York.

Krabbe P, Weijnen T (2003) Guidelines for analyzing and reporting EQ-5D outcomes. In:

Brooks R, Rabin RE, de Charro F (eds). The measurement and valuation of health status using EQ-5D: a European perspective. Kluwer Academic Press, Boston, pp 7-20.

Kushel MB, Vittinghoff E, Haas JS (2001) Factors associated with the health care utilization of homeless persons. JAMA 285:200-206.

Laird G (2007) Shelter. Homelessness in a growth economy: Canada's 21st century paradox. A report for the Sheldon Chumir Foundation for Ethics in Leadership. Sheldon Chumir Foundation for Ethics in Leadership and Gordon Laird, Calgary.

Lenskyj HJ (2002) Best Olympics ever? Social impacts of Sydney 2000. State University of New York Press, Albany.

McKenzie M, Tulsky JP, Long HL, Chesney M, Moss A (1999) Tracking and follow-up of marginalized populations: a review. J Health Care Poor Underserved 10:409-429.

Ministry of Housing and Social Development (2007) BC employment and assistance rates tables (effective July 1, 2007). http://www.eia.gov.bc.ca/mhr/rates.htm. Accessed 21 October 2010.

Piccinelli M, Tessari E, Bortolomasi M, Piasere O, Semenzin M, Garzotto N, et al. (1997) Efficacy of the alcohol use disorders identification test as a screening tool for hazardous alcohol intake and related disorders in primary care: a validity study. BMJ 314:420-424. Rabin R, de Charro F (2001) EQ-5D: a measure of health status from the EuroQol Group. Ann Med 33:337-343. 
Rosenthal D, Rotheram-Borus MJ, Batterham P, Mallett S, Rice E, Milburn NG (2007) Housing stability over two years and HIV risk among newly homeless youth. AIDS Behav 11:831841.

Ross NA, Dorling D, Dunn JR, Henriksson G, Glover J, Lynch J, et al. (2005) Metropolitan income inequality and working-age mortality: a cross-sectional analysis using comparable data from five countries. J Urban Health 82:101-110.

Ross NA, Wolfson MC, Dunn JR, Berthelot JM, Kaplan GA, Lynch JW (2000) Relation between income inequality and mortality in Canada and in the United States: cross sectional assessment using census data and vital statistics. BMJ 320:898-902.

Roy E, Haley N, Boudreau JF, Leclerc P, Boivin JF (2004) Mortality in a cohort of street youth in Montreal. JAMA 292:569-574.

Russell LB, Gadermann A, Hubley AM, Palepu A (2008) A new measure of quality of life: results from a pilot study of the health section of the quality of life for homeless and hardto-house individuals (QoLHHI) survey. Presented at the International Conference on Urban Health (ICUH), Vancouver, Canada. http://educ.ubc.ca/faculty/hubley/icuh2008/mdt.pdf.

Shaw JW, Johnson JA, Coon SJ (2005) US valuation of the EQ-5D health states: development and testing of the D1 valuation model. Med Care 43:203-20.

Social Planning and Research Council of BC (SPARC BC), Eberle Planning and Research, Jim Woodward \& Associates Inc., Graves J, Huhtala K, Campbell K, In Focus Consulting, Goldberg M (2008) Still on our streets. Results of the 2008 Metro Vancouver homeless count. Greater Vancouver Regional Steering Committee on Homelessness, 3 Ways to Home, Vancouver. 
Solorio MR, Rosenthal D, Milburn NG, Weiss RE, Batterham PJ, Gandara M, et al. (2008) Predictors of sexual risk behaviors among newly homeless youth: a longitudinal study. J Adolesc Health 42:401-409.

Statistics Canada (2010) Canadian Community Health Survey (CCHS). http://www.statcan.gc.ca/cgibin/imdb/p2SV.pl?Function=getSurvey \&SDDS=3226\&lang=en $\& \mathrm{db}=\mathrm{imdb} \& \mathrm{adm}=8 \& \mathrm{dis}$ $=2$. Accessed 21 October 2010 .

Toro PA, Bellavia CW, Daeschler CV, Owens BJ, Wall DD, Passero JM, et al. (1995) Distinguishing homelessness from poverty: a comparative study. J Consult Clin Psychol 63:280-289.

Tsemberis S, McHugo G, Williams V, Hanrahan P, Stefancic A (2007) Measuring homelessness and residential stability: the residential time-line follow-back inventory. J Community Psychol 35:29-42.

Ware JE, Kosinski M, Keller D (1995) SF-12: how to score the SF-12 physical and mental health summary scales, 2nd edn. The Health Institute, New England Medical Center, Boston. 
Table 1. Summary of longitudinal studies (follow-up $\geq 12$ months) of representative samples of homeless single adults.

\begin{tabular}{|c|c|c|c|c|c|c|c|}
\hline $\begin{array}{l}\text { Author } \\
\text { (Year) }\end{array}$ & Citation & City & $\begin{array}{l}\text { Population } \\
\text { Description (n) }\end{array}$ & $\begin{array}{l}\text { Follow-up } \\
\text { Duration }\end{array}$ & $\begin{array}{l}\text { Follow-up } \\
\text { Rate }\end{array}$ & $\begin{array}{l}\text { Housing Status at } \\
\text { end of Follow-up }\end{array}$ & $\begin{array}{l}\text { Observed Housing \& Health } \\
\text { Associations }\end{array}$ \\
\hline \multicolumn{8}{|l|}{ U.S. STUDIES } \\
\hline $\begin{array}{l}\text { Buchanan et } \\
\text { al. }(2009) *\end{array}$ & $\begin{array}{l}\text { Am J Public } \\
\text { Health 99 } \\
\text { Suppl 3: S675- } \\
\text { S680 }\end{array}$ & Chicago, IL & $\begin{array}{l}\text { HIV-positive } \\
\text { homeless } \\
\text { inpatients ( } \mathrm{n}= \\
\text { 105) } \\
\text { Race/ethnicity: } \\
88 \% \text { African- } \\
\text { American } \\
\text { 4\% Latino } \\
3 \% \text { White } \\
\text { 4\% Other }\end{array}$ & 12 months & $83 \%$ & $\begin{array}{l}\text { Among the } 54 \\
\text { participants in the } \\
\text { intervention } \\
\text { group, } 39(72 \%) \\
\text { reached interim } \\
\text { housing and } 35 \\
\text { (65\%) reached } \\
\text { permanent } \\
\text { housing. }\end{array}$ & $\begin{array}{l}\text { Survival with intact immunity was } \\
\text { higher among participants } \\
\text { receiving permanent housing with } \\
\text { intensive case management (vs. } \\
\text { usual care) at } 12 \text { month follow-up. } \\
\text { A significantly higher proportion } \\
\text { of participants in the intervention } \\
\text { group had undetectable viral loads } \\
\text { at the end of follow-up. }\end{array}$ \\
\hline $\begin{array}{l}\text { Caton et al. } \\
\text { (2005); } \\
\text { Schanzer et al. } \\
\text { (2007) }\end{array}$ & $\begin{array}{l}\text { Am J Public } \\
\text { Health } \\
95: 1753-1759 \\
\text { Am J Public } \\
\text { Health 97:464- } \\
469\end{array}$ & $\begin{array}{l}\text { New York } \\
\text { City, NY }\end{array}$ & $\begin{array}{l}\text { Newly homeless } \\
\text { adults } \\
(\mathrm{n}=445) \\
\text { Race/ethnicity: } \\
62 \% \text { African- } \\
\text { American, } \\
18 \% \text { Hispanic, } \\
20 \% \text { White or } \\
\text { Other }\end{array}$ & 18 months & $85 \%$ & $\begin{array}{l}307 \text { participants } \\
(81 \%) \text { returned to } \\
\text { community } \\
\text { housing during the } \\
\text { follow-up period. }\end{array}$ & $\begin{array}{l}\text { Younger age, better psychosocial } \\
\text { adjustment, recent or current } \\
\text { employment, adequate family } \\
\text { support, earned income, no current } \\
\text { drug treatment, and no arrest } \\
\text { history were associated with } \\
\text { shorter duration of homelessness. } \\
\text { Significant improvements in } \\
\text { health status (visual, dental, } \\
\text { podiatric, and blood pressure) } \\
\text { were observed over the follow-up } \\
\text { period. Use of health care services } \\
\text { was comparable among those who } \\
\text { found housing and those who } \\
\text { remained homeless. }\end{array}$ \\
\hline $\begin{array}{l}\text { Cohen et al. } \\
\text { (1997) }\end{array}$ & $\begin{array}{l}\text { Gerontologist } \\
37: 67-74\end{array}$ & $\begin{array}{l}\text { New York } \\
\text { City, NY }\end{array}$ & $\begin{array}{l}\text { Older homeless } \\
\text { female adults } \\
(\mathrm{n}=237) \\
\text { Race/ethnicity: } \\
51 \% \text { African- } \\
\text { American, } \\
34 \% \text { White, }\end{array}$ & 24 months & $85 \%$ & $\begin{array}{l}94 \text { participants } \\
(47 \%) \text { achieved } \\
\text { stable housing. }\end{array}$ & $\begin{array}{l}\text { Higher perceived social supports } \\
\text { and greater contact with } \\
\text { community agencies were } \\
\text { associated with achievement of } \\
\text { stable housing. }\end{array}$ \\
\hline
\end{tabular}




\begin{tabular}{|c|c|c|c|c|c|c|c|}
\hline $\begin{array}{l}\text { Author } \\
\text { (Year) }\end{array}$ & Citation & City & $\begin{array}{l}\text { Population } \\
\text { Description (n) }\end{array}$ & $\begin{array}{l}\text { Follow-up } \\
\text { Duration }\end{array}$ & $\begin{array}{l}\text { Follow-up } \\
\text { Rate }\end{array}$ & $\begin{array}{l}\text { Housing Status at } \\
\text { end of Follow-up }\end{array}$ & $\begin{array}{l}\text { Observed Housing \& Health } \\
\text { Associations }\end{array}$ \\
\hline & & & 10\% Hispanic & & & & \\
\hline $\begin{array}{l}\text { Dasinger and } \\
\text { Speiglman } \\
\text { (2007) }\end{array}$ & $\begin{array}{l}\text { AIDS Behav } \\
11: 128-139\end{array}$ & $\begin{array}{l}\text { San Francisco } \\
\text { Bay Area, CA }\end{array}$ & $\begin{array}{l}\text { Very low income } \\
\text { people with HIV } \\
\text { or AIDS and their } \\
\text { families }(\mathrm{n}=185) \text {; } \\
\text { eligible controls ( } \mathrm{n} \\
=218) \\
\text { Race/ethnicity: } \\
60 \% \text { Black } \\
28 \% \text { White } \\
8 \% \text { Hispanic } \\
4 \% \text { Asian/Pacific } \\
\text { Islander } \\
1 \% \text { Native } \\
\text { American }\end{array}$ & $\begin{array}{l}\text { Max. } 4 \\
\text { years, } 8 \\
\text { months }\end{array}$ & $\begin{array}{l}\text { Not } \\
\text { reported }\end{array}$ & $\begin{array}{l}99 \% \text { of } \\
\text { participants (vs. } \\
65 \% \text { of controls) } \\
\text { maintained rental } \\
\text { housing at } 6 \\
\text { month follow-up; } \\
99 \% \text { (vs. } 32 \% \text { ) at } \\
1 \text { year follow-up; } \\
96 \% \text { of } \\
\text { participants (vs. } \\
10 \% \text { ) at } 2 \text { year } \\
\text { follow-up }\end{array}$ & $\begin{array}{l}\text { Adjusted hazard ratio for time } \\
\text { spent in independent rental } \\
\text { housing was } 3.8 \text { times higher } \\
\text { among participants vs. controls; } \\
\text { time spent in rental housing } \\
\text { significantly lower among } \\
\text { individuals with mental health } \\
\text { issues or hepatitis. }\end{array}$ \\
\hline $\begin{array}{l}\text { Sadowski et al. } \\
\text { (2009) }\end{array}$ & $\begin{array}{l}\text { JAMA } \\
301: 1771-1778\end{array}$ & Chicago, IL & $\begin{array}{l}\text { Homeless adults } \\
\text { with chronic } \\
\text { medical illnesses } \\
(\mathrm{n}=405) \\
\text { Race/ethnicity: } \\
78 \% \text { African } \\
\text { American } \\
8 \% \text { Hispanic } \\
8 \% \text { White } \\
5 \% \text { Mixed or } \\
\text { other }\end{array}$ & 18 months & $\begin{array}{l}90 \% \text { for } \\
\text { interventio } \\
\mathrm{n} \text { group } \\
\text { and } 73 \% \\
\text { for usual } \\
\text { care group } \\
\text { (excl. } \\
\text { deaths) }\end{array}$ & $\begin{array}{l}116 \text { participants } \\
\text { (66\%) in the } \\
\text { intervention group } \\
\text { (vs. } 10 \text { in usual } \\
\text { care group) } \\
\text { reached stable } \\
\text { housing }\end{array}$ & $\begin{array}{l}\text { Compared to the usual care group, } \\
\text { participants receiving housing and } \\
\text { case management had reduced } \\
\text { hospitalizations, hospital days, and } \\
\text { emergency department visits } \\
\text { during the follow-up period. }\end{array}$ \\
\hline $\begin{array}{l}\text { Schwarcz et al. } \\
\text { (2009) }\end{array}$ & $\begin{array}{l}\text { BMC Public } \\
\text { Health 9:220 }\end{array}$ & $\begin{array}{l}\text { San Francisco, } \\
\text { CA }\end{array}$ & $\begin{array}{l}\text { Homeless adults } \\
\text { and adolescents } \\
\text { ( } \geq 13 \text { years old) } \\
\text { diagnosed with } \\
\text { AIDS ( } \mathrm{n}=676 \text { ) } \\
\text { Race/ethnicity: }\end{array}$ & $\begin{array}{l}\text { Various } \\
\text { (over a 10- } \\
\text { year } \\
\text { period) }\end{array}$ & $\begin{array}{l}\text { Not } \\
\text { reported }\end{array}$ & $\begin{array}{l}70 \text { participants } \\
(10 \%) \text { received } \\
\text { stable housing. }\end{array}$ & $\begin{array}{l}\text { Obtaining stable housing was } \\
\text { associated with an } 80 \% \text { reduction } \\
\text { in mortality. }\end{array}$ \\
\hline
\end{tabular}




\begin{tabular}{|c|c|c|c|c|c|c|c|}
\hline $\begin{array}{l}\text { Author } \\
\text { (Year) }\end{array}$ & Citation & City & $\begin{array}{l}\text { Population } \\
\text { Description (n) }\end{array}$ & $\begin{array}{l}\text { Follow-up } \\
\text { Duration }\end{array}$ & $\begin{array}{l}\text { Follow-up } \\
\text { Rate }\end{array}$ & $\begin{array}{l}\text { Housing Status at } \\
\text { end of Follow-up }\end{array}$ & $\begin{array}{l}\text { Observed Housing \& Health } \\
\text { Associations }\end{array}$ \\
\hline & & & $\begin{array}{l}41 \% \text { White } \\
39 \% \text { Black } \\
16 \% \text { Latino } \\
4 \% \text { Other }\end{array}$ & & & & \\
\hline $\begin{array}{l}\text { Toro et al. } \\
(1997) *\end{array}$ & $\begin{array}{l}\text { J Consult Clin } \\
\text { Psychol } \\
\text { 65:476-484 }\end{array}$ & Buffalo, NY & $\begin{array}{l}\text { Homeless adults } \\
\text { and families }(\mathrm{n}= \\
\text { 202), of whom } \\
158 \text { were single } \\
\text { adults. } \\
\\
\text { Race/ethnicity: } \\
54 \% \text { African- } \\
\text { American, } \\
34 \% \text { White, } \\
11 \% \text { Other }\end{array}$ & 18 months & $49 \%$ & $\begin{array}{l}\text { Controlled study } \\
\text { of an intervention } \\
\text { (intensive case } \\
\text { management). } \\
\text { In the control } \\
\text { group, number of } \\
\text { days homeless in } \\
\text { the last } 6 \text { months } \\
\text { decreased from } 95 \\
\text { days to } 10 \text { days. }\end{array}$ & $\begin{array}{l}\text { In the control group, little change } \\
\text { was observed in housing quality } \\
\text { despite a decrease in number of } \\
\text { days homeless. } \\
\text { In the intervention and control } \\
\text { groups combined, significant } \\
\text { improvements were observed over } \\
\text { time in physical health and } \\
\text { stressful life events. }\end{array}$ \\
\hline $\begin{array}{l}\text { Weinreb et al. } \\
\text { (2006) }\end{array}$ & $\begin{array}{l}\text { J Health Care } \\
\text { Poor } \\
\text { Underserved } \\
\text { 17:180-199 }\end{array}$ & $\begin{array}{l}\text { Worcester, } \\
\text { MA }\end{array}$ & $\begin{array}{l}\text { Low-income } \\
\text { housed and } \\
\text { homeless female } \\
\text { adults ( } \mathrm{n}=436) \text {. } \\
\text { Race/ethnicity: } \\
\text { 41\% White, } \\
32 \% \text { Hispanic, } \\
\text { 19\% African- } \\
\text { American }\end{array}$ & 24 months & $70 \%$ & Not reported & $\begin{array}{l}\text { Associations between housing and } \\
\text { health status were not reported. } \\
\text { Poor health status, non-white race, } \\
\text { and few social supports were } \\
\text { associated with frequent } \\
\text { emergency department visits. }\end{array}$ \\
\hline $\begin{array}{l}\text { Wolitski et al. } \\
\text { (2010); * } \\
\text { Kidder et al. } \\
(2007) *\end{array}$ & $\begin{array}{l}\text { AIDS Behav } \\
\text { 14:493-503; } \\
\text { AIDS Behav } \\
\text { 11:149-161 }\end{array}$ & $\begin{array}{l}\text { Baltimore, } \\
\text { MD; Chicago, } \\
\text { IL; Los } \\
\text { Angeles, CA }\end{array}$ & $\begin{array}{l}\text { Homeless and } \\
\text { unstably housed } \\
\text { persons living } \\
\text { with HIV/AIDS (n } \\
=630 \text { ) } \\
\text { Race/Ethnicity: } \\
\text { 78\% Black } \\
22 \% \text { Other }\end{array}$ & 18 months & $85 \%$ & $\begin{array}{l}82 \% \text { of } \\
\text { participants in the } \\
\text { intervention group } \\
\text { (rental assistance } \\
\text { with case } \\
\text { management) } \\
\text { were in stable } \\
\text { housing in the past } \\
90 \text { days compared } \\
\text { to } 51 \% \text { for } \\
\text { participants in } \\
\text { control group } \\
\text { (usual care with }\end{array}$ & $\begin{array}{l}\text { Significantly greater } \\
\text { improvements in housing stability } \\
\text { in intervention vs. control group. } \\
\text { Significant treatment effect } \\
\text { observed for depression, perceived } \\
\text { stress, and SF-12 physical health. } \\
\text { Being homeless for at least } 1 \text { night } \\
\text { in the past } 90 \text { days was associated } \\
\text { with more ER visits, higher } \\
\text { perceived stress, and higher } \\
\text { detectable viral load. }\end{array}$ \\
\hline
\end{tabular}




\begin{tabular}{|c|c|c|c|c|c|c|c|}
\hline $\begin{array}{l}\text { Author } \\
\text { (Year) }\end{array}$ & Citation & City & $\begin{array}{l}\text { Population } \\
\text { Description (n) }\end{array}$ & $\begin{array}{l}\text { Follow-up } \\
\text { Duration }\end{array}$ & $\begin{array}{l}\text { Follow-up } \\
\text { Rate }\end{array}$ & $\begin{array}{l}\text { Housing Status at } \\
\text { end of Follow-up }\end{array}$ & $\begin{array}{l}\text { Observed Housing \& Health } \\
\text { Associations }\end{array}$ \\
\hline & & & & & & $\begin{array}{l}\text { case } \\
\text { management). }\end{array}$ & \\
\hline $\begin{array}{l}\text { Zlotnick et al. } \\
\text { (1999); } \\
\text { Zlotnick et al. } \\
\text { (2003) }\end{array}$ & $\begin{array}{l}\text { J Community } \\
\text { Psychol } \\
\text { 27:209-224; } \\
\text { Subst Use } \\
\text { Misuse } \\
\text { 38:577-599 }\end{array}$ & $\begin{array}{l}\text { Alameda } \\
\text { County, CA }\end{array}$ & $\begin{array}{l}\text { Homeless adults } \\
(\mathrm{n}=564) \\
\text { Race/ethnicity: } \\
68 \% \text { African- } \\
\text { American, } \\
22 \% \text { White, } \\
9 \% \text { Other }\end{array}$ & 15 months & $70 \%$ & $\begin{array}{l}80 \% \text { of } \\
\text { participants exited } \\
\text { from } \\
\text { homelessness at } \\
\text { least once, but } \\
\text { only 15\% obtained } \\
\text { stable housing. }\end{array}$ & $\begin{array}{l}\text { Shorter duration of homelessness, } \\
\text { consistent receipt of entitlement } \\
\text { benefits, and obtaining } \\
\text { government subsidized housing } \\
\text { were associated with obtaining } \\
\text { stable housing. }\end{array}$ \\
\hline \multicolumn{8}{|c|}{ CANADIAN STUDIES } \\
\hline $\begin{array}{l}\text { Aubry et al. } \\
\text { (2003); } \\
\text { Aubry et al. } \\
\text { (2007); } \\
\text { Aubry et al. } \\
\text { (2011) }\end{array}$ & $\begin{array}{l}\text { City of } \\
\text { Ottawa; } \\
\text { University of } \\
\text { Ottawa; } \\
\text { Am J } \\
\text { Community } \\
\text { Psychol } 2011 \\
\text { May } 10 \text { [Epub } \\
\text { ahead of print] }\end{array}$ & Ottawa, ON & $\begin{array}{l}\text { Mixed population } \\
\text { of homeless } \\
\text { youth, single } \\
\text { adults, and } \\
\text { families }(\mathrm{n}=412) \text {, } \\
\text { of whom } 160 \text { were } \\
\text { single adults }\end{array}$ & 24 months & $62 \%$ & $\begin{array}{l}47 \% \text { of single men } \\
\text { and } 73 \% \text { of single } \\
\text { women obtained } \\
\text { housing. } \\
\text { Only } 10 \% \text { of } \\
\text { housed single men } \\
\text { were in subsidized } \\
\text { housing. }\end{array}$ & $\begin{array}{l}\text { Physical and mental health did not } \\
\text { change significantly among people } \\
\text { who obtained housing. } \\
\text { Higher quality of housing, as } \\
\text { perceived by respondents at } \\
\text { follow-up, was related to positive } \\
\text { changes in mental health } \\
\text { functioning. }\end{array}$ \\
\hline $\begin{array}{l}\text { Palepu et al. } \\
\text { (2010) }\end{array}$ & $\begin{array}{l}\text { PLoS One } \\
\text { 5:e11697 }\end{array}$ & $\begin{array}{l}\text { Vancouver, } \\
\text { BC }\end{array}$ & $\begin{array}{l}\text { Homeless and } \\
\text { vulnerably-housed } \\
\text { injection drug } \\
\text { users }(\mathrm{n}=992)\end{array}$ & $\begin{array}{l}\text { Min. } 12 \\
\text { months; } \\
\text { Max. } 48 \\
\text { months }\end{array}$ & $\begin{array}{l}\text { Not } \\
\text { reported }\end{array}$ & $\begin{array}{l}211 \text { participants } \\
(21 \%) \text { attained } \\
\text { stable housing } \\
\text { during the follow- } \\
\text { up period. }\end{array}$ & $\begin{array}{l}\text { Daily crack use, daily heroine } \\
\text { injection use, and current } \\
\text { enrolment in addiction treatment } \\
\text { at baseline were negatively } \\
\text { associated with attaining stable } \\
\text { housing. The same factors } \\
\text { remained significant in time- } \\
\text { dependent analyses. }\end{array}$ \\
\hline $\begin{array}{l}\text { Roy et al. } \\
(2003) ; \\
\text { Roy et al. } \\
(2010)\end{array}$ & $\begin{array}{l}\text { J Urban Health } \\
80: 92-105 ; \\
\text { J Urban Health } \\
87: 95-101\end{array}$ & Montreal, QC & $\begin{array}{l}\text { Cohort } 1: \text { Street } \\
\text { youth, aged } 14-25 \\
\text { years; Cohort } 2: \\
\text { Street youth aged } \\
14-23 \text { years }(n= \\
1,687)\end{array}$ & $\begin{array}{l}\text { Average of } \\
33 \text { months } \\
\text { (Cohort } 1)\end{array}$ & $\begin{array}{l}87 \% \\
\text { completed } \\
\text { at least } 1 \\
\text { follow-up } \\
\text { (Cohort 1) }\end{array}$ & Not reported & $\begin{array}{l}\text { Youths who reported recent } \\
\text { homelessness at a follow-up visit } \\
\text { had an adjusted mortality hazard } \\
\text { ratio of } 3.0 \text { during the subsequent } \\
\text { observation period for Cohort } 1 \\
\text { and } 2.8 \text { for Cohort } 2 \text {. Standardized } \\
\text { mortality ratios compared to the }\end{array}$ \\
\hline
\end{tabular}




\begin{tabular}{|c|c|c|c|c|c|c|c|}
\hline $\begin{array}{l}\text { Author } \\
\text { (Year) }\end{array}$ & Citation & City & $\begin{array}{l}\text { Population } \\
\text { Description (n) }\end{array}$ & $\begin{array}{l}\text { Follow-up } \\
\text { Duration }\end{array}$ & $\begin{array}{l}\text { Follow-up } \\
\text { Rate }\end{array}$ & $\begin{array}{l}\text { Housing Status at } \\
\text { end of Follow-up }\end{array}$ & $\begin{array}{l}\text { Observed Housing \& Health } \\
\text { Associations }\end{array}$ \\
\hline & & & & & & & $\begin{array}{l}\text { general population were } 11.6 \text { for } \\
\text { Cohort } 1 \text { and } 3.0 \text { for Cohort } 2 \text {. } \\
\text { Mortality rates were significantly } \\
\text { lower among Cohort } 2 \text {. }\end{array}$ \\
\hline \multicolumn{8}{|c|}{ INTERNATIONAL STUDIES } \\
\hline $\begin{array}{l}\text { Fichter and } \\
\text { Quadflieg } \\
\text { (2003); } \\
\text { Fichter and } \\
\text { Quadflieg } \\
\text { (2005) }\end{array}$ & $\begin{array}{l}\text { Subst Use } \\
\text { Misuse } \\
38: 395-427 \\
\text { Eur Arch } \\
\text { Psychiatry } \\
\text { Clin Neurosci } \\
\text { 255:111-120 }\end{array}$ & $\begin{array}{l}\text { Munich, } \\
\text { Germany }\end{array}$ & $\begin{array}{l}\text { Homeless male } \\
\text { adults } \\
(\mathrm{n}=265) \\
\text { Race/ethnicity: } \\
\text { Not reported }\end{array}$ & 36 months & $75 \%$ & $\begin{array}{l}103 \text { participants } \\
(56 \%) \text { achieved } \\
\text { stable housing. }\end{array}$ & $\begin{array}{l}\text { Men with lower education, history } \\
\text { of inpatient alcohol treatment, no } \\
\text { history of inpatient psychiatric } \\
\text { hospitalization, and shorter } \\
\text { duration of homelessness were } \\
\text { more likely to remain homeless. }\end{array}$ \\
\hline
\end{tabular}


Table 2. Components of baseline survey instrument for the Health and Housing in Transition (HHiT) Study

\begin{tabular}{|c|c|c|c|c|}
\hline Category / Variable & Measure(s) utilized & Selected survey question(s) & Values & Scales \\
\hline \multicolumn{5}{|l|}{ DEMOGRAPHICS } \\
\hline - $\operatorname{Sex}$ & - $\quad$ Self-report & - $\quad$ Your gender is...? & $\begin{array}{l}\text { - Male / Female / } \\
\text { Transgendered }\end{array}$ & \\
\hline - $\quad$ Age & - $\quad$ Self-report & - What is your date of birth? & - $\quad$ Years & \\
\hline - $\quad$ Marital status & - $\quad$ Self-report & - What is your marital status? & $\begin{array}{l}\text { - } \quad \text { Single, never married / } \\
\text { Separated, divorced / } \\
\text { Widowed / Married, incl. } \\
\text { common law / Partnered }\end{array}$ & \\
\hline - $\quad$ Relationship status & - $\quad$ Self-report & - Do you have a partner? & - $\quad$ Yes / No & \\
\hline - $\quad$ Race & - $\quad$ Self-report & $\begin{array}{l}\text { - To which racial or cultural group(s) } \\
\text { do you belong? }\end{array}$ & $\begin{array}{l}\text { - White / Black / First Nations } \\
\text { / East Asian / South Asian / } \\
\text { Southeast Asian / West } \\
\text { Asian / Hispanic / Other }\end{array}$ & \\
\hline - $\quad$ Country of birth & - $\quad$ Self-report & - What country were you born in? & & \\
\hline - $\quad$ Citizenship & - $\quad$ Self-report & - What is your citizenship status? & $\begin{array}{ll}\text { - } & \text { Citizen / Landed Immigrant / } \\
& \text { Refugee }\end{array}$ & \\
\hline $\begin{array}{l}\text { - Length of time in } \\
\text { [Toronto, Ottawa, } \\
\text { Vancouver] }\end{array}$ & - $\quad$ Self-report & $\begin{array}{l}\text { - How long have you lived in } \\
\text { [Toronto, Ottawa, Vancouver]? }\end{array}$ & $\begin{array}{l}\text { Days / Weeks / Months / } \\
\text { Years }\end{array}$ & \\
\hline $\begin{array}{l}\text { Language first } \\
\text { learned at home }\end{array}$ & - $\quad$ Self-report & $\begin{array}{l}\text { What is the language that you first } \\
\text { learned at home and still understand? }\end{array}$ & - English / French / Other & \\
\hline \multicolumn{5}{|l|}{ HOUSING } \\
\hline $\begin{array}{l}\text { - Proportion of time } \\
\text { housed }\end{array}$ & - $\mathrm{HTFBC}^{\mathrm{a}}$ & $\begin{array}{l}\text { - Tell me where you have been living } \\
\text { for the past } 2 \text { years }\end{array}$ & - Detailed housing history & \\
\hline $\begin{array}{ll} & \text { History of } \\
\text { homelessness }\end{array}$ & - $\quad$ Self-report & $\begin{array}{l}\text { - Have you ever been homeless? } \\
\text { - How old were you the first time you } \\
\text { were homeless? } \\
\text { Excluding the past } 2 \text { years, how } \\
\text { many days, weeks, months, or years } \\
\text { have you been homeless? } \\
\text { - Were you homeless with your } \\
\text { family? }\end{array}$ & $\begin{array}{ll}\text { - } & \text { Yes / No } \\
\text { - } & \text { Age } \\
\text { - } & \text { Length of time } \\
\text { - } & \text { Yes / No }\end{array}$ & \\
\hline
\end{tabular}

\footnotetext{
${ }^{a}$ Housing Timeline Follow-Back Calendar
} 


\begin{tabular}{|c|c|c|c|c|}
\hline - Education & - $\quad$ Self-report & $\begin{array}{l}\text { - How much school have you } \\
\text { completed? } \\
\text { - Are you currently enrolled in a } \\
\text { school or training program? }\end{array}$ & $\begin{array}{l}\text { Elementary / Middle school / } \\
\text { High school / Post- } \\
\text { secondary } \\
\text { - Full-time / Part-time }\end{array}$ & \\
\hline - Employment & - $\quad$ Self-report & $\begin{array}{ll}- & \text { Have you worked at a paid job? } \\
\text { - } & \text { Hours/week } \\
\text { - How many different paid jobs did } \\
\text { you have? }\end{array}$ & $\begin{array}{ll} & \text { Yes / No } \\
\text { - } & \text { Number of hours } \\
\text { - } & \text { Number of paid jobs }\end{array}$ & \\
\hline - Income & - $\quad$ Self-report & - What are your sources of income? & - $\quad$ Type and amount per month & \\
\hline \multicolumn{5}{|c|}{ INTERPERSONAL RESOURCES } \\
\hline - $\quad$ Social network size & - $\mathrm{SSNI}^{\mathrm{b}}$ & $\begin{array}{l}\text { Are there any people with whom you } \\
\text { feel at ease and can talk to about } \\
\text { personal issues? }\end{array}$ & $\begin{array}{l}\text { Number of persons } \\
\text { identified and relationship to } \\
\text { individual }\end{array}$ & - $\quad$ Count \\
\hline $\begin{array}{ll}- & \text { Provision of social } \\
\text { relationships }\end{array}$ & $\begin{array}{ll}-\mathrm{SPS}^{\mathrm{c}} \\
\\
\text { (8 items) }\end{array}$ & $\begin{array}{l}\text { If something went wrong, no one } \\
\text { would help me }\end{array}$ & $\begin{array}{ll} & \text { Strongly Agree / Agree / } \\
& \text { Disagree / Strongly Disagree } \\
\end{array}$ & $\begin{array}{ll}\text { Total score } \\
\text { (range: } 8-32)\end{array}$ \\
\hline \multicolumn{5}{|c|}{ COMMUNITY RESOURCES } \\
\hline - Social service use & - $\quad$ Self-report & - Which services did you use? & $\begin{array}{l}\text { - } \quad \text { Type and services used } \\
\text { - Number of times used }\end{array}$ & \\
\hline - $\quad$ Subsidized housing & $\begin{array}{ll}- & \text { Self-report } \\
\text { - } & \text { Cross-reference } \\
& \text { municipal list } \\
\end{array}$ & - Is your rent subsidized? & - Yes / No & \\
\hline \multicolumn{5}{|l|}{ RISK FACTORS } \\
\hline - Physical health & $\begin{array}{ll}\text { - } & \text { SF-12 } \\
& (12 \text { items }) \\
\text { - } & \text { EQ-5D } \\
& (5 \text { items }) \\
\text { - } & \mathrm{VAS}^{\mathrm{f}} \\
- & \text { NSHAPC }^{\mathrm{g}} \\
\text { - } & \mathrm{CCHS}\end{array}$ & $\begin{array}{l}\text { - In general, would you say your } \\
\text { health is...? } \\
\text { - Describe your health in terms of } \\
\text { mobility, self-care, usual activities, } \\
\text { pain, anxiety } \\
\text { - Rate your state of health } \\
\text { - Do you have any of the following } \\
\text { medical conditions? } \\
\text { - Have you had a... }\end{array}$ & 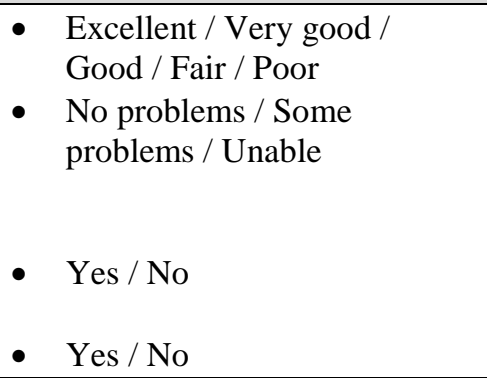 & $\begin{array}{l}\text { - Weighted score } \\
\text { (range: } 13-69 \text { ) } \\
\text { Weighted score } \\
\text { (range: }-0.11-1.00 \text { ) } \\
\text { - Range: } 0-100\end{array}$ \\
\hline
\end{tabular}

\footnotetext{
${ }^{\mathrm{b}}$ Social Support Network Instrument

${ }^{\mathrm{c}}$ Social Provisions Scale

d 12-item Short Form Health Survey

${ }^{\mathrm{e}}$ EuroQoL 5-Dimention Questionnaire

${ }^{\mathrm{f}}$ EuroQoL 5-Dimention Visual Analog Scale

${ }^{\mathrm{g}}$ National Survey of Homeless Assistance Providers and Clients
} 


\begin{tabular}{|c|c|c|c|c|}
\hline $\begin{array}{ll}\text { - } & \begin{array}{l}\text { Overall satisfaction } \\
\text { (quality of life) }\end{array} \\
\text { - } & \text { Impact of current } \\
\text { health }\end{array}$ & $\begin{array}{ll}- & \text { QoLHHI } \\
& (13 \text { items }) \\
- & \text { QoLHHI } \\
& (12 \text { items }) \\
\end{array}$ & $\begin{array}{l}\text { Toothache? } \\
\text { Pain in / around the jaw joints? } \\
\text { Other pain in the mouth? } \\
\text { - How do you feel about your current } \\
\text { health } \\
\text { Rate the impact of your physical } \\
\text { health on you }\end{array}$ & $\begin{array}{ll}\text { - } & \text { Very dissatisfied - Very } \\
\text { satisfied } \\
\text { - } \\
\text { Large negative impact - } \\
\text { Large positive impact } \\
\end{array}$ & $\begin{array}{ll}\text { - } & \text { Average score } \\
\text { (range: } 1-7) \\
\text { - } \\
\text { Average score } \\
(\text { range: } 1-7)\end{array}$ \\
\hline - Mental health & $\begin{array}{ll}\text { - } & \text { SF-12 } 2^{\mathrm{i}} \\
& (12 \text { items }) \\
\text { - } & \text { Self-report }\end{array}$ & $\begin{array}{l}\text { How much of the time have you felt } \\
\text { down? } \\
\text { - Have you been diagnosed with a } \\
\text { mental health problem? } \\
\text { - If yes, what was the diagnosis? }\end{array}$ & $\begin{array}{l}\text { - All of the time }- \text { None of the } \\
\text { time } \\
\text { - Yes / No } \\
\text { - List of diagnoses }\end{array}$ & $\begin{array}{l}\text { - Weighted score } \\
\text { (range: } 10-70 \text { ) }\end{array}$ \\
\hline - Unmet need for care & - $\quad$ Self-report & $\begin{array}{l}\text { Do you have a regular medical } \\
\text { doctor? } \\
\text { Have you needed care but were not } \\
\text { able to get help? } \\
\text { What were the reasons you were } \\
\text { unable to get help? }\end{array}$ & $\begin{array}{l}\text { - } \quad \text { Yes / No } \\
\text { - } \quad \text { Yes / No } \\
\text { - } \quad \text { List of reasons } \\
\end{array}$ & \\
\hline - Cigarette smoking & - $\mathrm{CCHS}^{\mathrm{j}}$ & - How often do you smoke? & $\begin{array}{ll}\text { - Daily / Occasionally / Not at } \\
\text { all }\end{array}$ & \\
\hline - $\quad$ Substance Use & $\begin{array}{ll}\text { - } & \text { Self-report } \\
& \\
\text { - } & \text { AUDIT }{ }^{\mathrm{k}} \\
& (10 \text { items }) \\
\text { - } & \text { DAST-10 } \\
& (10 \text { items }) \\
\text { - } & \text { Montreal Street } \\
& \text { Youth Study } \\
\end{array}$ & $\begin{array}{l}\text { - Which drugs have you used / } \\
\text { injected? } \\
\text { - How often did you have a drink } \\
\text { containing alcohol? } \\
\text { Did you abuse more than one drug at } \\
\text { a time? } \\
\text { What types of resources did you use } \\
\text { for your alcohol / drug use problems? }\end{array}$ & $\begin{array}{l}\text { - List of drugs used, frequency } \\
\text { of use, and injected use }\end{array}$ & $\begin{array}{l}\text { - Total score } \\
\text { (range: } 0-40) \\
\text { Total score } \\
\text { (range: } 0-10)\end{array}$ \\
\hline $\begin{array}{l}\text { - Legal and other } \\
\text { events }\end{array}$ & - $\quad$ Self-report & $\begin{array}{l}\text { Were you... } \\
\text { arrested by the police? } \\
\text { incarcerated? } \\
\text { beaten or physically attacked? } \\
\end{array}$ & $\begin{array}{ll}\text { - } & \text { Yes / No } \\
\text { - } & \text { Number of times }\end{array}$ & \\
\hline
\end{tabular}

\footnotetext{
${ }^{\mathrm{h}}$ Quality of Life for Homeless and Hard-to-House Individuals Instrument

i 12 -item Short Form Health Survey

${ }^{\mathrm{j}}$ Canadian Community Health Survey

${ }^{\mathrm{k}}$ Alcohol Use Disorders Identification Test

${ }^{1}$ 10-item Drug Abuse Screen Test
} 
Submission to the International Journal of Public Health: Special Issue on Housing and Health Promotion

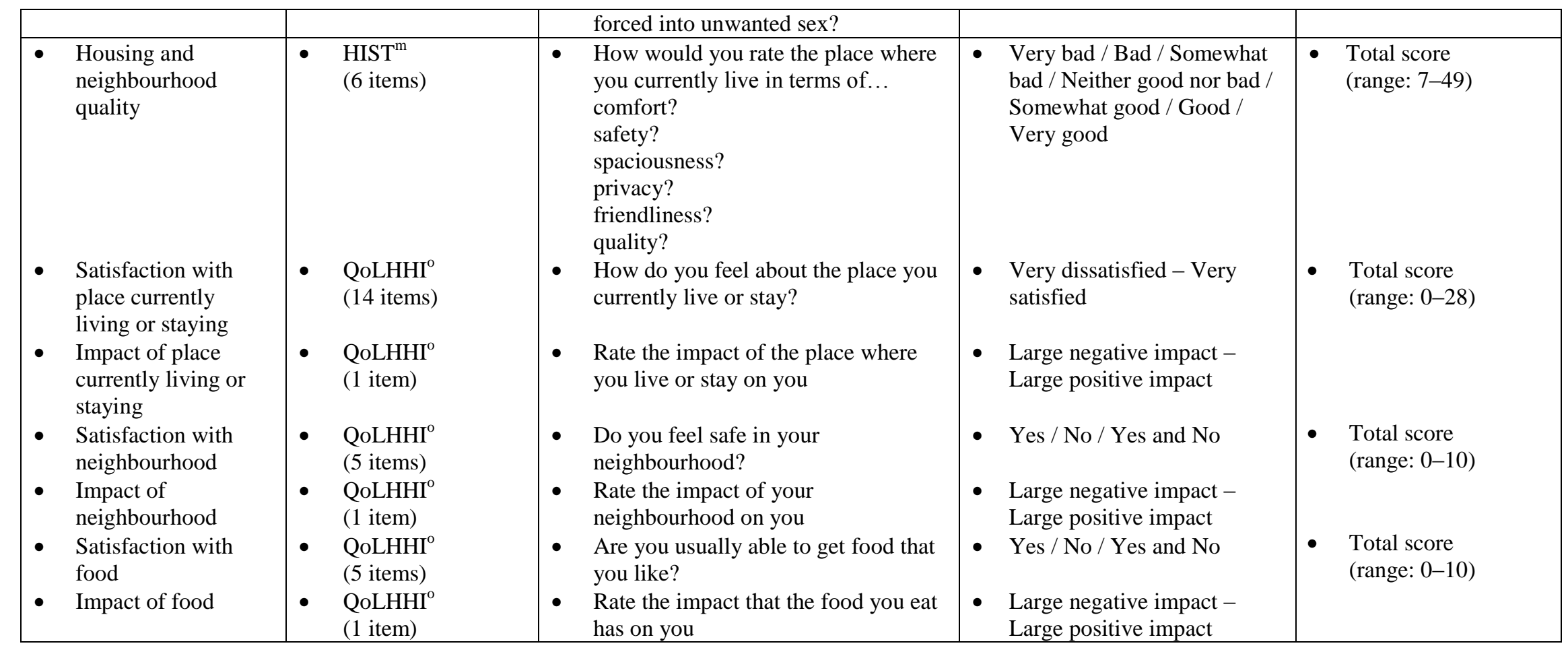

\footnotetext{
m Toro's HIST Instrument
} 
Table 3. Characteristics of homeless and vulnerably housed participants at baseline in

Vancouver, Toronto, and Ottawa, Canada, 2009

\begin{tabular}{|c|c|c|c|c|}
\hline Variable & $\begin{array}{l}\text { All Participants } \\
\qquad(\mathrm{n}=1192)\end{array}$ & $\begin{array}{l}\text { Homeless } \\
(\mathbf{n}=595)\end{array}$ & $\begin{array}{l}\text { Vulnerably } \\
\text { Housed } \\
(\mathbf{n}=597)\end{array}$ & p-value \\
\hline Age group, n (\%) & & & & 0.171 \\
\hline$<30$ years & $160(13.5)$ & $91(15.4)$ & $69(11.6)$ & \\
\hline $30-39$ years & $295(24.8)$ & $150(25.3)$ & $145(24.3)$ & \\
\hline 40-49 years & $443(37.2)$ & 207 (34.9) & $236(39.5)$ & \\
\hline$\geq 50$ years & $292(24.5)$ & $145(24.5)$ & $147(24.6)$ & \\
\hline Gender, n (\%) & & & & 0.034 \\
\hline Male & $781(65.7)$ & $373(62.7)$ & $408(68.8)$ & \\
\hline Female & $389(32.7)$ & $215(36.1)$ & $174(29.3)$ & \\
\hline Transgender & $18(1.5)$ & $7(1.2)$ & $11(1.9)$ & \\
\hline Marital status, n (\%) & & & & 0.301 \\
\hline Single/never married & $687(58.0)$ & $339(57.4)$ & $348(58.6)$ & \\
\hline Divorced/separated & $309(26.1)$ & $164(27.8)$ & $145(24.4)$ & \\
\hline Widowed & $30(2.5)$ & $18(3.1)$ & $12(2.0)$ & \\
\hline Married/common law & $82(6.9)$ & $35(5.9)$ & $47(7.9)$ & \\
\hline Partnered, not married & $77(6.5)$ & $35(5.9)$ & $40(7.1)$ & \\
\hline Born in Canada, n (\%) & $1,002(84.6)$ & $474(79.8)$ & $528(89.3)$ & $<0.001$ \\
\hline Racial/cultural group, n (\%) & & & & $<0.001$ \\
\hline White & $722(62.5)$ & $358(62.1)$ & $364(62.9)$ & \\
\hline Black/African-Canadian & $106(9.2)$ & $66(11.4)$ & $40(6.9)$ & \\
\hline First Nations/Aboriginal & 205 (17.7) & $74(12.8)$ & $131(22.6)$ & \\
\hline Mixed ethnicity & $64(5.5)$ & $38(6.6)$ & $26(4.5)$ & \\
\hline Other & $59(5.1)$ & $41(7.1)$ & $18(3.1)$ & \\
\hline Highest level of education, n (\%) & & & & $<0.001$ \\
\hline Some high school & $529(44.7)$ & $231(39.0)$ & $298(50.5)$ & \\
\hline $\begin{array}{l}\text { Completed high school or } \\
\text { equivalent }\end{array}$ & $277(23.4)$ & $146(24.6)$ & $131(22.2)$ & \\
\hline $\begin{array}{l}\text { Some post-secondary } \\
\text { education or higher }\end{array}$ & 377 (31.9) & $216(36.4)$ & $161(27.3)$ & \\
\hline $\begin{array}{l}\text { Employed in past } 12 \text { months, } \mathrm{n} \\
(\%)\end{array}$ & $474(39.8)$ & $245(41.3)$ & $229(38.4)$ & 0.320 \\
\hline $\begin{array}{l}\text { Monthly income, (CDN dollars) } \\
\text { median (Q1-Q3) }\end{array}$ & $900(543-1427)$ & $900(385-1600)$ & $900(600-1330)$ & 0.078 \\
\hline $\begin{array}{l}\text { Current monthly rent, (CDN } \\
\text { dollars) median (Q1-Q3) }\end{array}$ & $--^{\mathrm{a}}$ & $--^{a}$ & $388(343-450)$ & \\
\hline $\begin{array}{l}\text { Currently living in subsidized } \\
\text { housing, } \mathrm{n}(\%)\end{array}$ & $--^{a}$ & $--^{a}$ & $222(40.0)$ & \\
\hline $\begin{array}{l}\text { Lifetime duration of } \\
\text { homelessness (in years), median } \\
\text { (Q1-Q3) }\end{array}$ & $2.8(1.1-6.6)$ & $2.7(1.1-6.6)$ & $3.0(1.0-6.6)$ & 0.992 \\
\hline SF-12 PCS, ${ }^{b}$ mean (SD) & $44.5(11.3)$ & $45.3(11.8)$ & $43.7(10.7)$ & 0.016 \\
\hline SF-12 MCS, ${ }^{b}$ mean (SD) & $39.1(13.0)$ & $38.3(13.1)$ & $39.9(13.0)$ & 0.040 \\
\hline $\begin{array}{l}\text { Number of chronic health } \\
\text { conditions, }{ }^{\mathrm{c}} \mathrm{n}(\%)\end{array}$ & & & & $<0.001$ \\
\hline
\end{tabular}

\footnotetext{
${ }^{\text {a }}$ Not applicable

${ }^{\mathrm{b}}$ On a scale where 50 is the mean and 10 is the standard deviation in the US general population.
} 
Submission to the International Journal of Public Health: Special Issue on Housing and Health Promotion

\begin{tabular}{|lcccc|}
0 & $151(12.7)$ & $94(15.8)$ & $57(9.6)$ & \\
1 & $250(21.0)$ & $138(23.2)$ & $112(18.8)$ & \\
2 & $198(16.6)$ & $91(15.3)$ & $107(17.9)$ & \\
$\geq 3$ & $593(49.8)$ & $272(45.7)$ & $321(53.8)$ & \\
\hline $\begin{array}{l}\text { Ever diagnosed with a mental } \\
\text { health problem, } \mathrm{n}(\%)\end{array}$ & $607(51.7)$ & $288(49.0)$ & $319(54.3)$ & 0.066 \\
\hline
\end{tabular}

${ }^{\mathrm{c}}$ Chronic health conditions include high blood pressure; heart disease; asthma; COPD (includes emphysema and chronic bronchitis); cirrhosis; Hepatitis B or C; intestinal or stomach ulcers; urinary incontinence; bowel disorders; arthritis; problems walking, lost limb, or other physical handicap; HIV/AIDS; epilepsy; fetal alcohol syndrome or fetal alcohol spectrum disorder; head injury; glaucoma; cataracts; cancer, diabetes; or anemia. 